\title{
The feeding habit of the Cyprinidae Rastrineobola argentea in its new habitat, lakes Bulera and Ruhondo, two Rwandan lakes (Eastern Africa)
}

\author{
M. Isumbisho(1,2), P. Petit ${ }^{(3)}$, J.B. Gashagaza( ${ }^{(4)}$, J. Moreau ${ }^{(5)}$ \\ Received November 13, 2010 \\ Revised May 11, 2011 \\ Accepted May 12, 2011
}

\section{ABSTRACT}

Key-words: feeding habits, invasive species, Rastrineobola argentea, great lakes, East Africa
Rastrineobola argentea Pellegrin 1904, a small pelagic endemic cyprinid from lake Victoria was introduced into lake Bulera (Rwanda) in 1991 in order to develop a fishery. From there, it accidentally colonized lake Ruhondo. To study its biology in its new habitat, samples were collected in 2007 and size and the feeding habits of the fish were analyzed. $R$. argentea is smaller in lake Bulera $(41.8 \pm 6 \mathrm{~mm}$ ) than in lake Ruhondo (mean total body length: $72.6 \pm 15 \mathrm{~mm}$ ). The mean total body length in lake Bulera is less than its size at the first maturity in lake Victoria $(47 \mathrm{~mm})$. Differences in size structure of fish between lakes Bulera and Ruhondo is attributed mainly to the food availability in the two lakes. In lake Bulera, the fish feeds on six food items with plant remnants dominant. In lake Ruhondo, $R$. argentea is a zooplanktivorous feeder like in lake Victoria. The dominant prey is a cladoceran species, Daphnia sp. which has not been observed in lake Bulera during the sampling period.

\section{RÉSUMÉ}

Habitude alimentaire de Rastrineobola argentea (Cyprinidae) dans son nouvel habitat, les lacs Bulera et Ruhondo, deux lacs du Rwanda (Afrique de l'Est)

\author{
Mots-clés: \\ habitudes \\ alimentaires, \\ espéces \\ invasives, \\ Rastrineobola \\ argentea, \\ grands lacs, \\ Afrique de l'Est
}

Rastrineobola argentea Pellegrin 1904, un petit cyprinidé pélagique, endémique du lac Victoria a été introduit dans le lac Bulera (Rwanda) en 1991 en vue d'y permettre le développement de la pêcherie. De là, il a accidentellement colonisé le lac Ruhondo. Dans le but d'étudier sa biologie dans son nouvel habitat, les échantillons pour l'analyse de sa taille et de son habitude alimentaire ont été collectés en 2007. Les résultats indiquent que ce poisson est plus petit dans le lac Bulera $(41,8 \pm 6 \mathrm{~mm})$ que dans le lac Ruhondo $(72,6 \pm 15 \mathrm{~mm})$. La longueur moyenne totale du corps dans le lac Bulera est plus petite que sa taille à la première maturité dans le lac Victoria $(47 \mathrm{~mm})$. La différence observée entre les deux lacs est attribuable principalement à la disponibilité alimentaire. En effet, dans le lac Bulera, six proies constituent la ration alimentaire de $R$. argentea avec une dominance de débris végétaux. Dans le lac Ruhondo par contre, $R$. argentea est zooplanctonophage comme au lac Victoria. La proie dominante est un cladocère, Daphnia sp., qui n'a pas été observé dans le lac Bulera durant la période d'échantillonnage.

(1) Unité d'Enseignement et de Recherche en Hydrobiologie Appliquée (UERHA), Département

de Biologie-Chimie, ISP/Bukavu, P.O. Box 854 Bukavu, Democratic Republic of Congo, isumbisho@yahoo.fr

(2) Faculté des Sciences Agronomiques et Environnement, UEA/Bukavu, PO Box 3223 Bukavu, Democratic

Republic of Congo

(3) Food and Agriculture Organization of the United Nations, Bujumbura, Burundi

(4) Université Nationale du Rwanda, PO Box 137 Butare, Rwanda

(5) Laboratoire d'Écologie Fonctionnelle ECOLAB, INPIENSAT, PO Box 32607, 31326 Castanet Tolosan, France 


\section{INTRODUCTION}

Rastrineobola argentea Pellegrin 1904 is a small endemic zooplanktivorous cyprinid fish (maximum standard length of $9.0 \mathrm{~cm}$ in Lake Victoria; Eccles, 1992), from Lake Victoria, East Africa. In this lake, it is one of the most abundant fish species and of high commercial interest (e.g. Mwebaza-Ndawula, 1998; Wanink, 1999; Wanink and Witte, 2000).

To enhance the fish production and thus develop a flourishing fishery, $R$. argentea (locally called "Indagala"), was introduced into Lake Bulera (Rwanda) in 1991. Its fishery developed and, since 2006, this fish was curiously found in lake Ruhondo, supposing the later was accidentally colonized from Lake Bulera. The estimation of the exploitable stock of the fish in these lakes has not been achieved but catches from fishermen are estimated at about 40 t/year from Lake Bulera and about 20 t/year in lake Ruhondo.

Until now, nothing was known about the biology and ecology of this fish in its new habitat whereas its fishery is expected to become flourishing. Therefore, this study aims at (i) reporting a preliminary investigation on the feeding habits of Rastrineobola argentea in these two lakes, using the stomach contents analysis, and at (ii) understanding how this species copes to exploit different resources available in these ecosystems.

\section{MATERIALS AND METHODS}

\section{$>$ (I) SITES LOCATION AND SAMPLING PERIOD}

Lake Bulera ( $1^{\circ} 26^{\prime} \mathrm{S}$ and $\left.29^{\circ} 46^{\prime} \mathrm{E}\right)$ and lake Ruhondo $\left(1^{\circ} 30^{\prime} \mathrm{S}\right.$ and $\left.29^{\circ} 44^{\prime} \mathrm{E}\right)$ are the two highest lakes of Rwanda, situated at 1862 and 1764 m a.s.l., respectively (Van den Bossche and Bernascek, 1990). The surface and catchments area of lake Bulera (51.8 and $563 \mathrm{~km}^{2}$, respectively) are about twice of that of lake Ruhondo (26.6 and $198 \mathrm{~km}^{2}$, respectively) (Figure 1). The water volume is also about four times higher in lake Bulera $\left(4.5 \mathrm{~km}^{3}\right)$ than in lake Ruhondo $\left(1 \mathrm{~km}^{3}\right.$ ). The two lakes differ also by their depths (max. $179 \mathrm{~m}$ in lake Bulera and $68 \mathrm{~m}$ in lake Ruhondo). These lakes are close to each other and connected. Lake Ruhondo is situated downstream lake Bulera, with a hydroelectric dam between the two.

Water and fish samples were collected in 5 stations from each lake, in both open and littoral waters, during a programme of scientific investigations aimed at a better understanding of their biotopes.

\section{> (II) LIMNOLOGICAL VARIABLES MEASUREMENTS}

Limnological variables [dissolved oxygen (DO), temperature, conductivity and $\mathrm{pH}$ ] were measured using a Hydrolab DS4a multiprobe (Loveland, USA). Euphotic depth (Zeu, depth at which light is $1 \%$ of subsurface light) was derived from estimates of the vertical light attenuation coefficient from Secchi depth, using a coefficient $(k=1.34 /($ Secchi disk depth in $\mathrm{m})$ ) obtained by calibration with measurement of PAR (photosynthetic attenuation rate) attenuation with LICOR quantum sensors at each sampling site. Depth of the mixed layer $(\mathrm{Zm})$ was estimated from the depth of the top of the thermocline, as shown by the temperature, oxygen and $\mathrm{pH}$ vertical profiles.

\section{>(III) FISH SAMPLING}

Fish samples for Length frequency distribution analysis were collected from catches of fishermen who operate night-time lift-nets in deep waters. Samples of large fish were caught with experimental gill-nets of various mesh sizes (10 to $30 \mathrm{~mm}$ knot to knot) in the shallow littoral zones. The maximum depth exploited by lift-nets is 15 to $20 \mathrm{~m}$ in these two lakes, but 


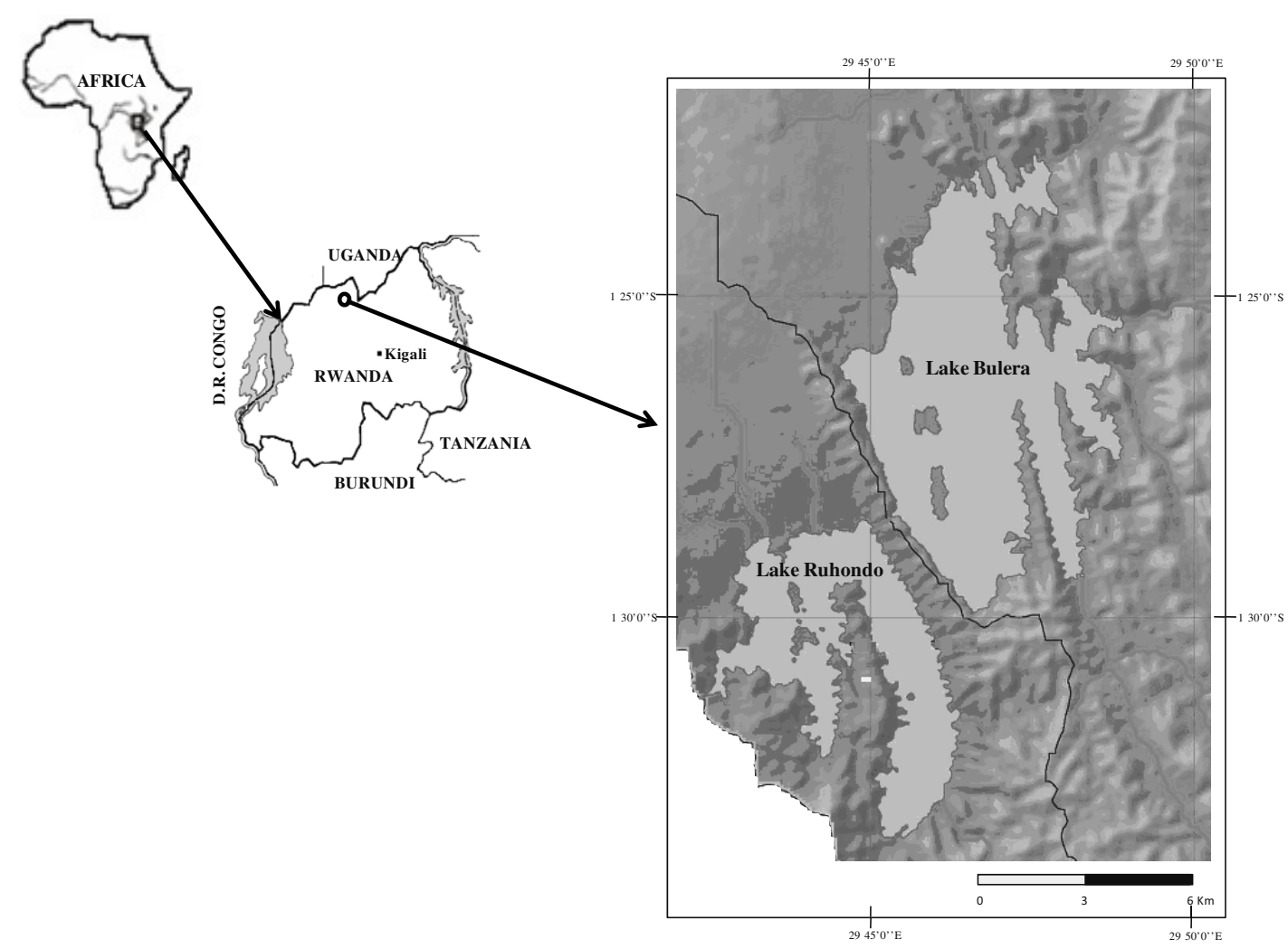

\section{Figure 1}

Geographic situation of lakes Bulera and Ruhondo.

echosounding measurements implemented during the study showed that $R$. argentea colonizes deeper waters in both lakes (about $30 \mathrm{~m}$ ). The gill-nets were set in waters at $<4 \mathrm{~m}$ and left overnight, while the fishers cast their lift-net every $3 \mathrm{~h}$, from around 10 p.m. until dawn. Stomach contents were taken from fish caught by both lift-nets and gill nets.

\section{> (IV) FISH BODY LENGTH MEASUREMENT AND STOMACH CONTENTS ANALYSIS}

The total fish body length ( $T L$ in $\mathrm{mm}$ ) was measured using a Calipers square. A total of 921 and $357 R$. argentea from lakes Bulera and Ruhondo, respectively, were measured. The data recorded were used for length frequency analysis using a one way ANOVA to compare the two sets of data distribution.

Only 100 and 83 stomachs, preserved in 5\% buffer formalin from fish from lakes Bulera and Ruhondo, respectively, were examined under a binocular microscope in the laboratory. Depending on the extent of the digestion, the different items were determined with variable taxonomic accuracy. Occurrence index (lo \%) and volumetric index ( $/ v \%)$, using the point estimation method developed by Hynes (1950), were used to describe the diet of $R$. argentea and were combined into the synthetic Lauzanne's alimentary index la (Lauzanne, 1976). In order to characterize the diet by identifying the importance of common prey items consumed by $R$. argentea, the contribution of each prey item to the total diet was quantified using its la percentage estimated as:

$$
\% l a_{\mathrm{i}}=\frac{I A_{i}}{\sum_{i=1}^{n} I A_{i}} \times 100 .
$$


With $l a=0.01 \times l o \times I V($ Lauzanne, 1976) and $n$ the number of different prey items $(i)$.

\section{RESULTS}

\section{>(I) LIMNOLOGICAL VARIABLES IN THE WATER COLUMN OF BULERA AND RUHONDO LAKES}

Physicochemical parameters measured during the sampling period are presented in Table I. The mixed zone was $10 \mathrm{~m}$ in lake Bulera, four times deeper that of Ruhondo (2.5 m). Maximum measured water transparency was $5 \mathrm{~m}$ in lake Bulera and $2.1 \mathrm{~m}$ in lake Ruhondo while the euphotic depth was about twice $(12 \mathrm{~m})$ in Bulera than in Ruhondo $(5.2 \mathrm{~m})$. The water is less mineralized (conductivity: $102 \mu \mathrm{S} \cdot \mathrm{cm}^{-1}$ ) in lake Bulera than in lake Ruhondo $\left(253 \mu \mathrm{S} \cdot \mathrm{Cm}^{-1}\right)$. The mean dissolved oxygen concentration, temperature and $\mathrm{pH}$ in the mixed zone were, respectively, $6.3 \mathrm{mg} \cdot \mathrm{L}^{-1}$ (about $80 \%$ of saturation), $21.1^{\circ} \mathrm{C}$ and 9.7 in lake Bulera and $7.0 \mathrm{mg} \cdot \mathrm{L}^{-1}$ (about $95 \%$ of saturation), $22.6{ }^{\circ} \mathrm{C}$ and 10.4 in Ruhondo. The oxygen depletion in the water column was observed at about $35 \mathrm{~m}$ depth in lake Bulera, and $8 \mathrm{~m}$ in Ruhondo (Figure 2).

\section{Table I}

Limnological variables (average values for $\mathrm{Zm}$ ) and other physics parameters of lakes Bulera and Ruhondo (Van den Bossche and Bernascek, 1990, except (*): data collected during the present study).

\begin{tabular}{|c|c|c|}
\hline Parameter & Lake Bulera & Lake Ruhondo \\
\hline Catchments area $\left(\mathrm{km}^{2}\right)$ & 563 & 198 \\
\hline Altitude (m) & 1862 & 1764 \\
\hline Surface $\left(\mathrm{km}^{2}\right)$ & 51.8 & 26.6 \\
\hline Volume $\left(\mathrm{km}^{3}\right)$ & 4.5 & 1 \\
\hline Maximum depth (m) & 179 & 68 \\
\hline Average depth (m) & 80 & 40 \\
\hline Mixing zone: $Z m(m)\left(^{*}\right)$ & 10 & 2.5 \\
\hline Temperature $\left({ }^{\circ} \mathrm{C}\right)\left({ }^{*}\right)$ & 21.1 & 22.6 \\
\hline Dissolved oxygen $\left(\mathrm{mg} \cdot \mathrm{L}^{-1}\right)\left(^{\star}\right)$ & 6.3 & 7.0 \\
\hline Conductivity $\left(\mu \mathrm{S} \cdot \mathrm{cm}^{-1}\right)\left(^{\star}\right)$ & 102.1 & 253.0 \\
\hline Transparency Secchi $(\mathrm{m})\left(^{*}\right)$ & 5.0 & 2.1 \\
\hline Euphotic depth: Zeu (m) $\left(^{\star}\right)$ & 12 & 5.2 \\
\hline $\mathrm{pH}(*)$ & 9.7 & 10.4 \\
\hline
\end{tabular}

\section{> (III) SIZE FREQUENCIES DISTRIBUTIONS IN THE TWO LAKES}

The difference in the average total body length of $R$. argentea $(41.8 \pm 6 \mathrm{~mm}$ in lake Bulera and $72.6 \pm 15 \mathrm{~mm}$ in lake Ruhondo) was highly significant $(P<.0001$, Fisher PLSD) during the sampling period. The range of sizes from experimental fishing nets was from 25 to $65 \mathrm{~mm}$ in lake Bulera and from 34 to $99 \mathrm{~mm}$ in Lake Ruhondo (Figure 3). The size frequencies for the fish of the two lakes show also an important difference (Figure 3). During the sampling period, only one modal size class (between 40 and $44 \mathrm{~mm}$ ) was observed in lake Bulera, while in Lake Ruhondo, two modal classes were evident, with the most abundant between 80 and $84 \mathrm{~mm}$.

\section{> (III) COMPOSITION OF THE DIET AND IMPORTANCE OF DIFFERENT PREYS FOR R. ARGENTEA IN LAKES BULERA AND RUHONDO}

The composition of the diet of $R$. argentea is different in the two lakes (Table II). In lake Bulera, six categories of prey were found: phytoplankton (mainly Diatoms and Microcystis spp.), zooplankton (cyclopoid copepods), insects (larvae of Chaoborus spp.), scales of fish, nematods 


\section{Lake Bulera}

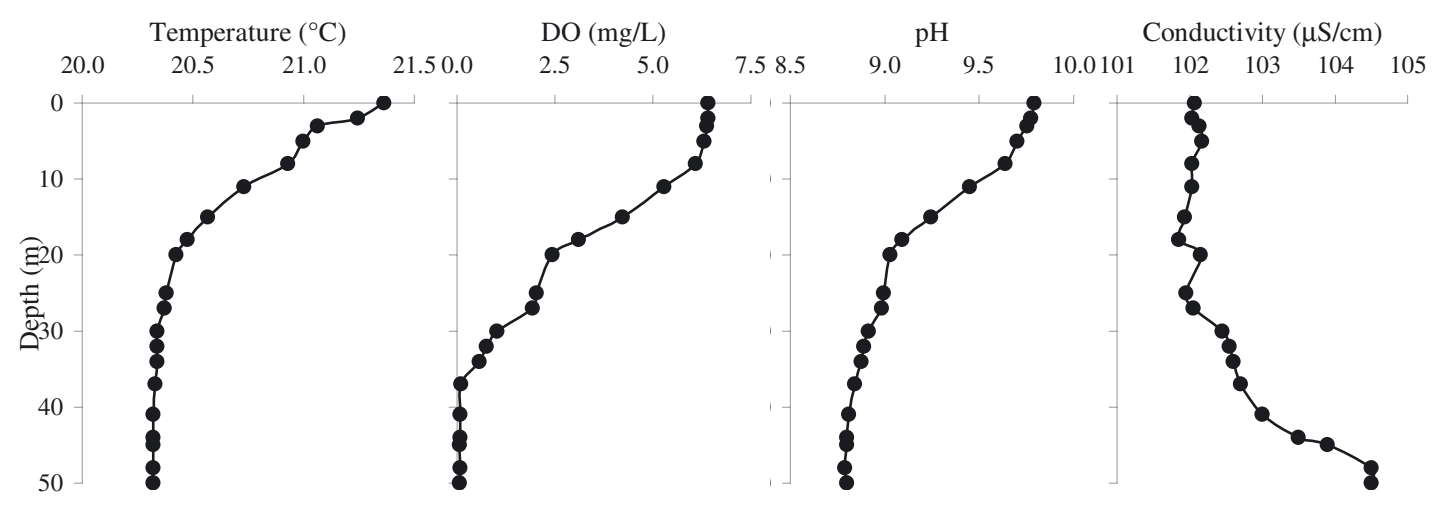

Lake Ruhondo

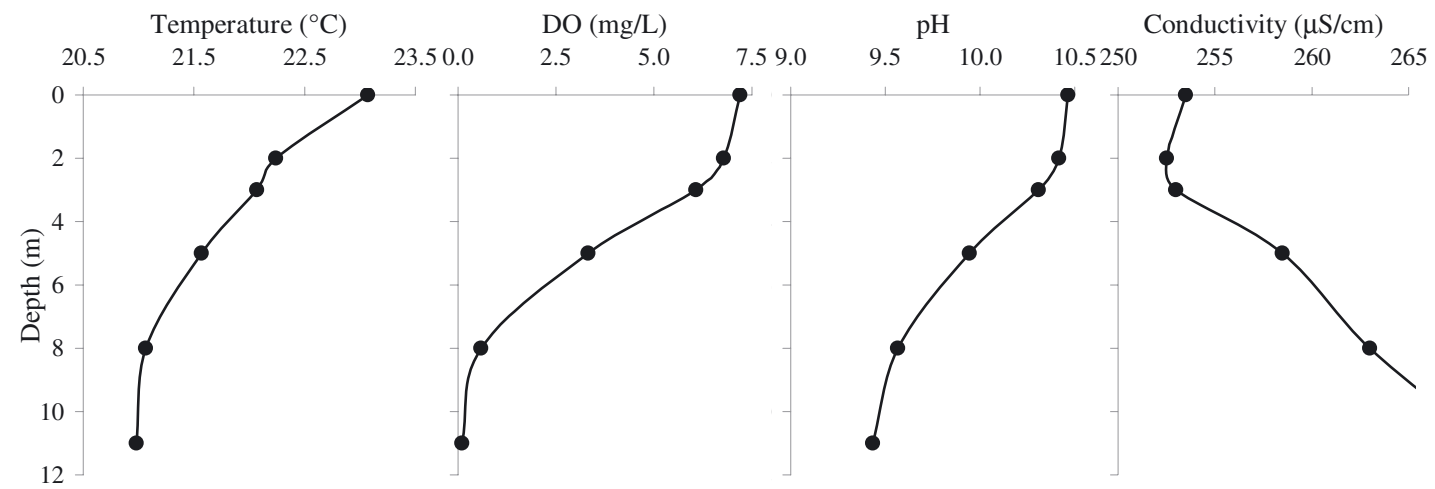

\section{Figure 2}

Temperature, $\mathrm{DO}, \mathrm{pH}$ and water conductivity vertical profiles in the water column of lakes Bulera and Ruhondo.

and plant remnants. In lake Ruhondo, only three prey categories were found: Phytoplankton (mostly Microcystis spp.), zooplankton (cyclopoid copepods and a cladoceran Daphnia sp.) and insects (Chaborus larvae).

Quantitatively, the difference is also important (Table II). In lake Bulera, $R$. argentea showed a preference for plant remnants, with more than $70 \%$ of stomachs full of this item $(/ o=72.7 \%)$. Only $27 \%$ of stomachs analysed contained zooplankton $(I o=27.3 \%)$ while phytoplankton $(l o=18.2 \%)$, scales of fish $(l o=18.2 \%)$ and nematods $(9.1 \%)$ were observed in less than $20 \%$ of stomachs. In lake Ruhondo, $R$. argentea consumes mainly zooplankton. Practically all stomachs analysed contained Daphnia sp. $(I o=100 \%)$ and $45 \%$ contained copepods $(I o=45.5 \%)$. Phytoplankton was consumed by about $28 \%(I O=27.8 \%)$ and the insects by only $9 \%$ of fishes analysed.

The relative contribution of the different preys to the total volume of the diet consumed by the fish in the two lakes reveals the same trend (Figure 4). In lake Bulera, plant remnants were the major volumetric proportion of the diet $(l v=58 \%)$. Zooplankton and Phytoplankton constituted, respectively, $18.9 \%$ and $10 \%$ of the total volume of food consumed. Volumetric proportions of other prey items were negligible. In lake Ruhondo, zooplankton occupied at least $98 \%$ of the volume of the diet consumed by $R$. argentea $(I V=98.4 \%)$.

When examining the alimentary Lauzanne's index (Ia) for each prey item, the difference in the feeding habit of the fish is very clear (Table II). In each lake, only one prey item was dominant while others were accessories. 

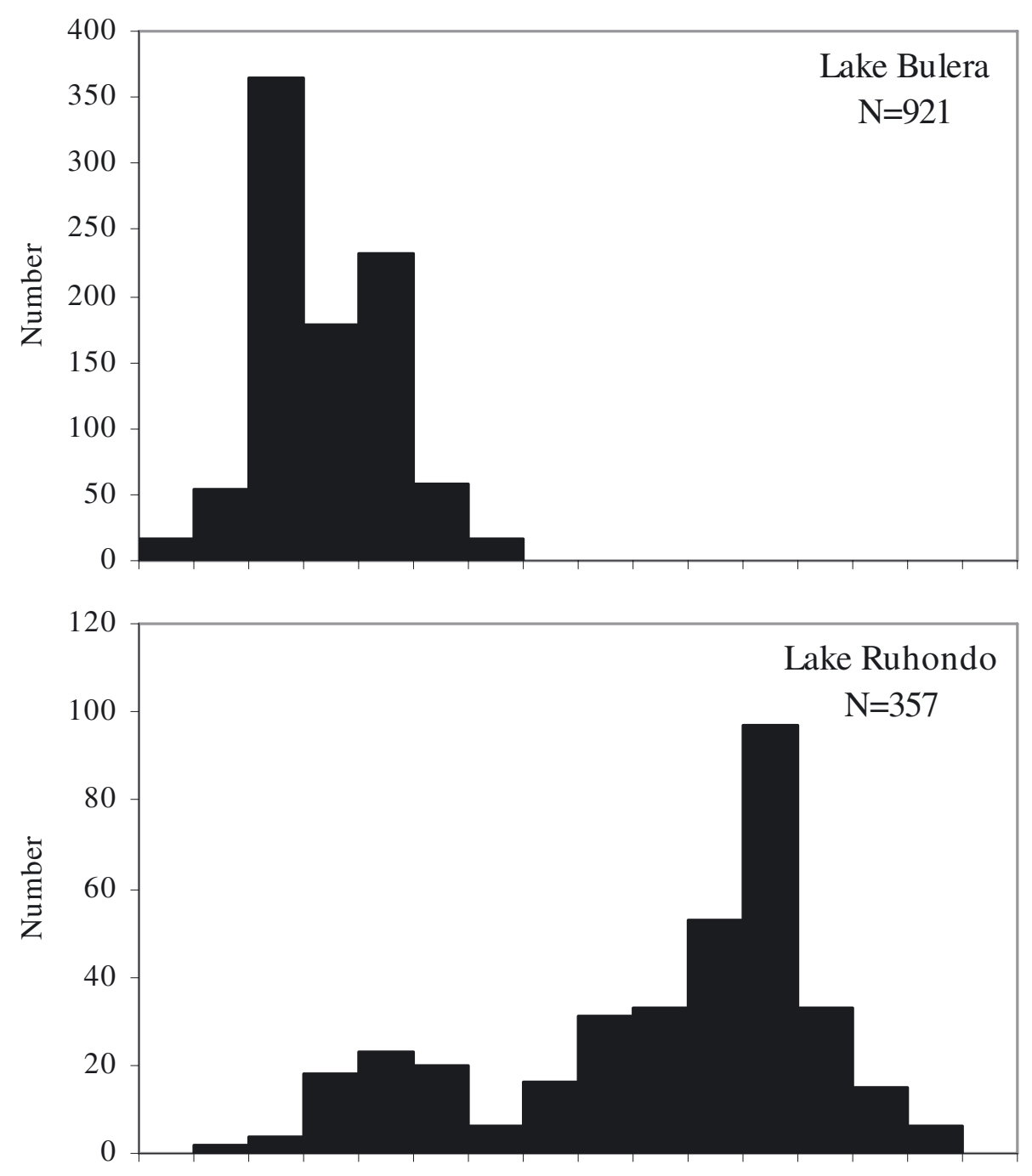

\section{Figure 3}

Length frequency distributions of R. argentea in lakes Bulera and Ruhondo as obtained from lift nets operated by fishermen.

\section{DISCUSSION}

The introduction of the zooplanktivorous cyprinid $R$. argentea in 1991 in lake Bulera aimed at exploiting a vacant pelagic ecological niche in order to enhance fish productivity. The accidental colonization of lake Ruhondo by $R$. argentea from lake Bulera is similar to that of Cahora Bassa by Limnothrissa miodon (Boulenger, 1906) from lake Kariba (Marshall, 1991). It is known that introduction of exogenous species into ecosystems, which occurred quite often in the past (e.g. Lodge et al., 1998; Pardo et al., 2009), is now considered as one of the leading threats to the biodiversity of ecosystems (e.g. Sala et al., 2000; Baxter et al., 2004; Lasram and Mouillot, 2009; Leprieur et al., 2009). For example, the Tanganyika sardine $L$. miodon was introduced into lake Kivu for the same reason i.e. to exploit the vacant pelagic feeding niche (empty niche hypothesis, Simberloff, 1995). At least within the context of the importance of fisheries for the local population, the introduction of $L$. miodon into lake 


\section{Table II}

Relative importance of preys consumed by $R$. argentea in lakes Bulera and Ruhondo (lo = occurrence index in $\%, I v=$ volumetric index in $\%$ and la $(\%)=$ the percentage of Lauzanne's index).

\begin{tabular}{|l|c|c|c|c|c|c|}
\hline \multirow{2}{*}{ Food items } & \multicolumn{3}{|c|}{ Lake Bulera } & \multicolumn{3}{c|}{ Lake Ruhondo } \\
\cline { 2 - 7 } & IO (\%) & IV (\%) & Ia (\%) & Io (\%) & IV (\%) & Ia (\%) \\
\hline Phytoplankton & $\mathbf{1 8 . 2}$ & $\mathbf{1 0}$ & $\mathbf{3 . 6}$ & $\mathbf{2 7 . 8}$ & $\mathbf{0 . 8}$ & $\mathbf{0 . 2}$ \\
Diatoms & 9.1 & 0.9 & - & - & - & - \\
Microcystis spp. & 9.1 & 9.1 & - & 27.3 & 0.8 & - \\
Zooplankton & $\mathbf{2 7 . 3}$ & $\mathbf{1 8 . 9}$ & $\mathbf{9 . 6}$ & $\mathbf{1 0 0}$ & $\mathbf{9 8 . 4}$ & $\mathbf{9 7 . 7}$ \\
Copepods Cyclopoids & 27.3 & 18.9 & - & 45.5 & 11.3 & - \\
Daphnia sp. & - & - & - & 100 & 87.1 & - \\
Insects & $\mathbf{9 . 1}$ & $\mathbf{3 . 6}$ & $\mathbf{0 . 6}$ & $\mathbf{9 . 1}$ & $\mathbf{0 . 8}$ & $\mathbf{0 . 1}$ \\
Chaoborus larvae & 9.1 & 3.6 & - & 9.1 & 0.8 & - \\
Scales of fish & $\mathbf{1 8 . 2}$ & $\mathbf{6 . 8}$ & $\mathbf{2 . 4}$ & - & - & - \\
Nematods & $\mathbf{9 . 1}$ & $\mathbf{2 . 7}$ & $\mathbf{0 . 5}$ & - & - & - \\
Plants remnant (rubbish) & $\mathbf{7 2 . 7}$ & $\mathbf{5 8}$ & $\mathbf{8 3 . 0}$ & - & - & - \\
\hline
\end{tabular}

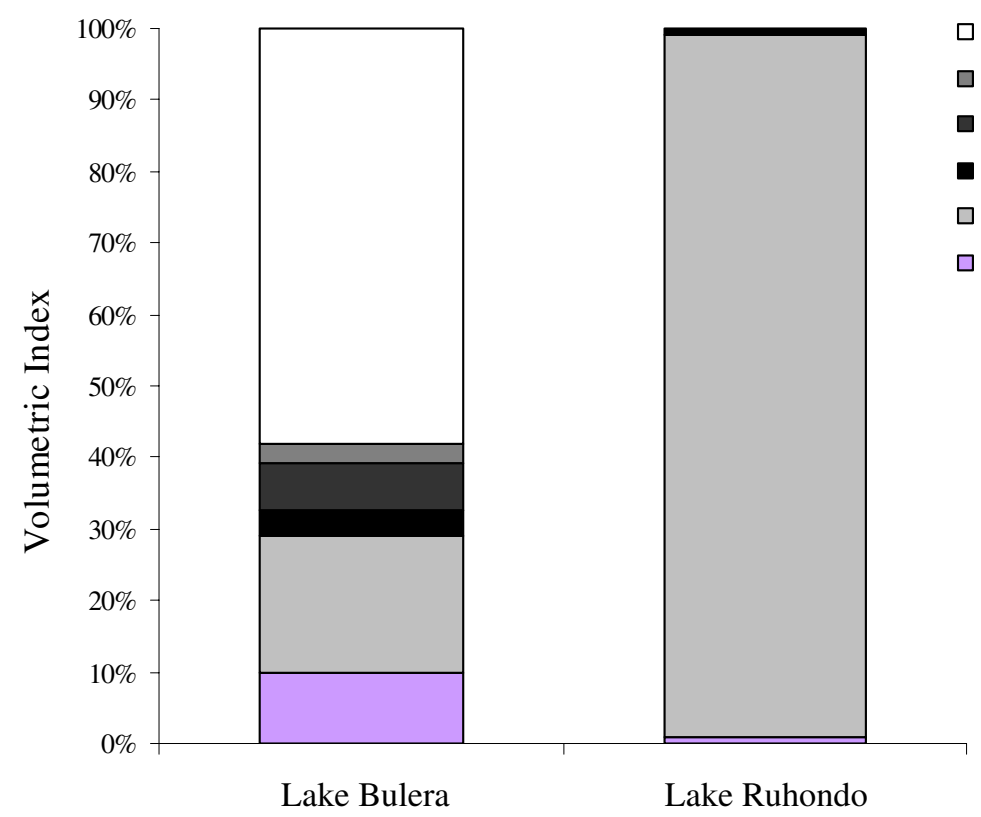

$\square$ Plant remnants

$\square$ Nematods

$\square$ Scales of fish

Insects

$\square$ Zooplankton

$\square$ Phy toplankton

Volumetric importance of different prey items in the stomach contents of R. argentea in lakes Bulera and Ruhondo.

Kivu has been a success (Marshall, 1995; Roest, 1999). However, important changes in the food web were reported, particularly concerning zooplankton community: disappearance of large species, particularly Daphnia curvirostris Eylmann 1878 and decrease of the total zooplankton biomass (Dumont, 1986). Exotic species introductions are a global problem that deserves global attention and understanding (Halls and Mills, 2000).

The limnological variables suggest that lakes Bulera and Ruhondo differ in their productivity, leading to potential effects on the availability of resources exploited by $R$. argentea as, according to Hobæk et al. (2002), the lake area as well as its depth can influence its species richness. Rastrineobola argentea reaches larger sizes in lake Ruhondo than in lake Bulera. This may be due to the existence of better ecological conditions in lake Ruhondo. Regarding the temperature, Baensch and Riehl (1997) reported the range of 22 to $26{ }^{\circ} \mathrm{C}$ to be the preference for this species. During the sampling period, in the rainy season, the mean temperature in the $Z m$ of lake Bulera was $21.1^{\circ} \mathrm{C}$, which is lower to the minimal value of this 
range, compared to the situation in lake Ruhondo $\left(22.6^{\circ} \mathrm{C}\right)$. Given that in the region, the surface water temperature of large lakes decreases in the dry season (Isumbisho et al., 2006, Sarmento et al., 2006), it is likely that the temperature in lake Bulera remains lower $\left(22^{\circ} \mathrm{C}\right)$ all over the year, which is not suitable for $R$. argentea.

The reliance on plant remnants in the diet of $R$. argentea in lake Bulera is likely to be a suboptimal food. In lake Ruhondo, the diet is dominated by zooplankton as it is for $R$. argentea in lake Victoria (Wanink et al., 2002). Although R. argentea can also feed on shrimps, other plankton invertebrates and insects (Witte and de Winter, 1995), plant remnants have never been reported in its diet. In lake Ruhundo, large cladocerans, particularly Daphina spp., are the preferred food of $R$. argentea while the zooplankton analysis showed that biomass and abundance of copepods were greater than cladocerans ones in the two lakes (Isumbisho et al., unpublished).

The preferential consumption of large prey by opportunistic feeders, when they are available, is well known in freshwaters (e.g. Lazzaro, 1987; Marshall, 1993; Soranno et al., 1993). Cladocerans in general are often selected by visual predators because of their visibility and behaviour (Mookerji et al., 1998; Korinek, 1999). The preference of large body-size cladocerans by opportunistic visual feeders enhances their vulnerability and might even lead to their disappearance (Cochrane, 1984; Dumont, 1986; Marshall, 1991; Allison et al., 1996; Marshall, 1997; Mandima, 1999, 2000; Hoffman et al., 2001; Gliwicz, 2002; Isumbisho et al., 2004).

The size of $R$. argentea in lake Ruhondo, where it feeds predominantly on Daphnia sp., is about twice the size found in lake Bulera. Besides, its mean size $(41.8 \pm 6 \mathrm{~mm}$; Max. $65 \mathrm{~mm})$ in lake Bulera is less than its size at first maturity in lake Victoria $(47 \mathrm{~mm}$, according to Wandera, 1990) where it originates from. In lake Ruhondo, the fish reaches a total body length of $99 \mathrm{~mm}$, which is more than in lake Victoria where individuals rarely reach a length greater than $90 \mathrm{~mm}$ (Eccles, 1992). This suggests that lake Ruhondo provides a very favorable habitat for $R$. argentea, whereas food resources in lake Bulera are poor.

The success of exotic species depends on their ability to establish and reproduce in invaded communities (Elton, 1958). The proficiency with which an invader avoids predators, pathogens and competitors determines, in part, its abundance and potential ecological impact on the community it has invaded (Coulas et al., 1998). Likewise, invasion theory predicts that invasions are most likely to succeed in systems that lack strong predators and in which native species diversity is low (Elton, 1958; Lodge, 1993). Different aspects of the biology and ecology of $R$. argentea in the two neighbouring lakes are to be investigated for a sustainable management of the fisheries. For example, in lake Victoria, the main predators of $R$. argentea are known (Wanink, 1999) but nothing about this aspect has been investigated in the two lakes of Rwanda. Finally, an important question is the reason of the absence of Daphnia in the samples collected from lake Bulera. The possibility that it was there before the $R$. argentea introduction remains to be considered. This should be investigated in further studies.

\section{ACKNOWLEDGEMENTS}

We are grateful to the UERHA (Unité d'Enseignement et de Recherche en Hydrobiologie Appliquée) team for scientific and technical support, especially to Mrs Georges ALUNGA and Pascal MASILYA for field and laboratory assistance.

We also thank the PAIGELAC Authorities (Projet d' Aménagement Intégré des Lacs Intérieurs) in Rwanda and the BCEOM (Montpellier, France) for financial and technical support for the field surveys.

\section{REFERENCES}

Allison E.H., Irvine K., Thompson A.B. and Ngatunga B.P., 1996. Diets and food consumption rates of pelagic fish in lake Malawi, Africa. Freshw. Biol., 35, 489-515.

Baensch H.A. and Riehl R., 1997. Aquarien Atlas, Band 5, Mergus Verlag, Melle, Germany, 1148 p. 
Baxter C.V., Fausch K.D., Murakami M. and Chapman P.L., 2004. Fish invasion restructures stream and forest food webs by interrupting reciprocal prey subsidies. Ecology, 85, 2656-2663.

Cochrane K.L., 1984. The influence of food availability, breeding seasons and growth on commercial catches of Limnothrissa miodon (Boulenger) in lake Kariba. J. Fish Biol., 24, 623-635.

Coulas R.A., Macisaac H.J. and Dunlop W., 1998. Selective predation on an introduced zooplankter (Bythotrephes cederstroemi) by lake herring (Coregonus artedii) in Harp lake, Ontario. Freshw. Biol., 40, 343-355.

Dumont H.J., 1986. The Tanganyika sardine in lake Kivu: another ecodisaster for Africa? Env. Conserv., 13, 143-148.

Eccles D.H., 1992. Field guide to the freshwater fishes of Tanzania, FAO species identification sheets for fishery purposes. In: FAO, Roma, Italy, V, 145 p.

Elton C.S., 1958. The Ecology of Invasions by Animals and Plants, Chapman and Hall, London.

Gliwicz Z.M., 2002. On the different nature of top-down and bottom-up effects in pelagic food webs. Freshw. Biol., 47, 2296-2312.

Halls S.R. and Mills E.L., 2000. Exotic species in large lakes of the world. AEHM, 3, 105-135.

Hobæk A., Manca M. and Andersen T. 2002. Factors influencing species richness in lacustrine zooplankton. Acta Oecol., 23, 155-163.

Hoffman J.C., Smith M.E. and Lehman J.T., 2001. Perch or plankton: top-down control of Daphnia by yellow perch (Perca flavescens) or Bythotrephes cederstroemi in an inland lake? Freshw. Biol., 46, 759-775.

Hynes H.B.N., 1950. The food of freshwater sticklebacks (Gasterosteus aculeatus and Pygosteus pungutius) with a review of methods used in studies of the food of fishes. J. Anim. Ecol., 19, 36-58.

Isumbisho M., Kaningini M., Descy J.-P. and Baras E., 2004. Seasonal and diel variations in diet of the young stages of Limnothrissa miodon in lake Kivu, Eastern Africa. J. Trop. Ecol., 20, 73-83.

Isumbisho M., Sarmento H., Kaningini B., Micha J.-C. and Descy J.P., 2006. Zooplankton of lake Kivu, East Africa: half a century after the Tanganyika sardine introduction. J. Plankton Res., 28, 971-989.

Korinek V., 1999, A guide to limnetic species of Cladocera of African inland waters (Crustacea, Branchiopoda) (using the morphology of parthenogenetic females), International Association of Theoretical and Applied Limnology No. 1, Geneva, 57 p.

Lasram F.B.R. and Mouillot D., 2009. Increasing southern invasion enhances congruence between endemic and exotic Mediterranean fish fauna. Biol. Invasions, 11, 697-711.

Lauzanne L., 1976. Régimes alimentaires et relations trophiques des poissons du lac Tchad. Cahiers Orstom, Série Hydrobiologie, 10, 267-310.

Lazzaro X., 1987. A review of planktivorous fishes: Their evolution, feeding behaviours, selectivities, and impacts. Hydrobiol., 146, 97-167.

Leprieur F., Brosse S., García-Berthou E., Oberdorff T., Olden J.D. and Townsend C.R., 2009. Scientific uncertainty and the assessment of risks posed by non-native freshwater fishes. Fish Fish., 10, 88-97.

Lodge D.M., 1993. Biological invasions: lessons for ecology. Trends Ecol. Evol., 8, 133-137.

Lodge D.M., Stein R.A., Brown K.M., Covich A.R., Brönmark C., Garvey J.E. and Klosiewski S.P., 1998. Predicting impact of freshwater exotic species on native biodiversity: Challenges in spatial scaling. Aust. J. Ecol., 23, 53-67.

Mandima J.J., 1999. The food and feeding behaviour of Limnothrissa miodon (Boulenger, 1906) in lake Kariba, Zimbabwe. Hydrobiol., 407, 175-182.

Mandima J.J., 2000. Spatial and temporal variations in the food of the sardine Limnothrissa miodon (Boulenger, 1906) in lake Kariba, Zimbabwe. Fish. Res., 48, 197-203.

Marshall B.E., 1991. The impact of introduced sardine Limnothrissa miodon on the ecology of lake Kariba. Biol. Conserv., 55, 151-165.

Marshall B.E., 1993. Biology of the African clupeid Limnothrissa miodon with reference to its small size in artificial lakes. Rev. Fish Biol. Fisheries, 3, 17-38.

Marshall B.E., 1995. Why is Limnothrissa miodon such a successful introduced species and is there anywhere else we should put it? In: Pitcher T.J. and Hart P.J.B. (eds.), The Impact of Species Changes in African lakes, Chapman \& Hall, London, 527-545. 
Marshall B.E., 1997. A review of zooplankton ecology in lake Kariba. In: Moreau J. (ed.), Advanced in the Ecology of lake Kariba, University of Zimbabwe Publications, Harare, Zimbabwe, 102-119.

Mookerji N., Heller C., Meng H.J., Bürgi H.R. and Müller R., 1998. Diel and seasonal patterns of food intake and prey selection by Coregonus sp. in re-oligotrophicated lake Lucerne, Switzerland. J. Fish. Biol., 52, 443-457.

Mwebaza-Ndawula L., 1998. Distribution and abundance of zooplankton and Rastrineobola argentea (Pisces: Cyprinidae) and their trophic interactions in northern lake Victoria, East Africa, Ph.D. thesis, University of Vienna.

Pardo R., Vila I. and Capella J.J., 2009. Competitive interaction between introduced rainbow trout and native silverside in a Chilean stream. Environ. Biol. Fish., 86, 353-359.

Roest F.C., 1999. Introduction of a pelagic fish into a large natural lake: lake Kivu, Central Africa. In: van Densen, W.L.T. and Morris M.J. (eds.), Fish and Fisheries of lakes and Reservoirs in Southeast Asia and Africa, Westbury Publishing, Otley, 327-338.

Sala O.E., III F.S.C., Armesto J.J. et al., 2000. Global Biodiversity Scenarios for the Year 2100. Science, $287,1770-1774$.

Sarmento H., Isumbisho M. and Descy J.P., 2006. Phytoplankton ecology of lake Kivu (Eastern Africa). J. Plankton Res., 28, 815-829.

Simberloff D., 1995. Why do introduced species appear to devastate islands more than mainland areas? Pac. Sci., 49, 87-97.

Soranno P.A., Carpenter S.R. and He X., 1993. Zooplankton biomass and body size. In: Carpenter S.R. and Kitchell J.F. (eds.), The Trophic Cascade in lakes, Cambridge University Press, Cambridge, 172-188.

Van den Bossche J.P. and Bernacsek G., 1990. Source book for the inland fishery resources of Africa FAO CIFA Technical Paper 18, Vol. 1.

Wandera S.B., 1990. The exploitation of small pelagic fishes of the great lakes of Africa with reference to the mukene (Rastrineobola argenteus) fishery of the northern waters of lake Victoria. In: IAC, Fisheries of the African Great lakes, Papers presented at the International Symposium on resource use and conservation of the African great lakes, Bujumbura, 1989, Int. Agric. Centre, Wageningen, Netherlands. Fish. Aquac. Unit. Occas, 67-74.

Wanink J.H., 1999. Prospects for the fishery on the small pelagic Rastrineobola argentea in lake Victoria. Hydrobiologia, 407, 183-189.

Wanink J.H. and Witte F., 2000. Rapid morphological changes following niche shift in the zooplanktivorous cyprinid Rastrineobola argentea from lake Victoria. Neth. J. Zool., 60, 256-259.

Wanink J.H., Katunzi E.F.B., Goudswaard K.P.C., Witte F. and van Densen W.L.T., 2002. The shift to smaller zooplankton in lake Victoria cannot be attributed to the 'sardine' Rastrineobola argentea (Cyprinidae). Aquat. Living Resour., 15, 37-43.

Witte F. and de Winter W., 1995. Appendix II. Biology of the major fish species of lake Victoria. In: Witte F. and Van Densen W.L.T. (eds.), Fish Stocks and Fisheries of Lake Victoria. A handbook for field observations, Samara Publishing Limited, Dyfed, Great Britain, 301-320. 